\title{
Assessing patient satisfaction with implant prosthetic work. A preliminary questionnaire-based study
}

\author{
Evaluarea gradului de satisfacţie al pacienţilor cu privire la lucrările \\ supraimplantare. Un studiu preliminar bazat pe chestionar
}

\author{
Arin Sava' ${ }^{1}$ Ondine Lucaciu', Simion Bran², Florin Onişor², Sorina Sava ${ }^{3}$, \\ Alexandru Meşter ${ }^{1}$, Ovidiu Aghiorghiesei ${ }^{1}$, Roxana Bălan' ${ }^{4}$, Radu Septimiu Câmpian' ${ }^{1}$ \\ ${ }^{1}$ Departamentul de Reabilitare Orală, Sănătate Orală şi Managementul Cabinetului Dentar, \\ Universitatea de Medicină şi Farmacie „Iuliu Haţieganu“, Cluj-Napoca, România \\ ${ }^{2}$ Departamentul de Chirurgie Orală şi Maxilo-facială, \\ Universitatea de Medicină şi Farmacie „Iuliu Haţieganu“, Cluj-Napoca, România \\ ${ }^{3}$ Departamentul de Materiale Dentare, Universitatea de Medicină şi Farmacie „luliu Haţieganu“, \\ Cluj-Napoca, România \\ ${ }^{4}$ Spitalul Clinic Judeţean de Urgenţă, Cluj-Napoca, România
}

\begin{abstract}
Objective. To evaluate the quality of life of edentulous patients with implant prosthetic work.

Methods. Retrospective study, between 2015 and 2016, with a group of 50 patients in the over-implantation phase. Patients responded to a satisfaction questionnaire following overdenture prosthesis.

Results. Overdenture has improved the quality of life of patients by regaining their self-esteem, regaining the aesthetic, phonetic and mastication functions, as well as the possibility of using a solid consistency diet without the occurrence of pain.

Conclusion. The use of overdenture prosthesis is a treatment that gives patients satisfaction from all points of view (functional, psychological, aesthetic and economic). To reflect the reality, future studies will need to obtain information from a larger number of subjects from different backgrounds, being treated in different clinics.
\end{abstract}

Keywords: oral health-related quality of life, overdenture, implant, edentulous

\section{REZUMAT}

Obiectiv. Evaluarea satisfacţiei calităţi vieţii pacienţilor edentaţi total prin protezare supraimplantară Material şi metodă. S-a realizat un studiu retrospectiv, în perioada 2015-2016, cu un lot de 50 de pacienţi aflaţi în faza de tratament supraimplantar. Pacienţii au răspuns la un chestionar de evaluare a gradului de satisfacţie în urma protezării supraimplantare.

Rezultate. Prin protezarea supraimplantară s-a obţinut o îmbunătăţire a calităţii vieţii pacienţilor prin recâştigarea încrederii în propria imagine, redobândirea funcţiilor de masticaţie, estetică şi fonaţie, precum şi posibilitatea utilizării alimentelor de consistenţă solidă, fără apariţia durerilor în zonele reabilitate implantoprotetic.

Concluzii. Utilizarea protezării supraimplantare reprezintă o variantă de tratament care oferă satisfacţie pacienţilor din toate punctele de vedere (funcţional, psihologic, estetic, dar şi economic). Pentru a reflecta corect realitatea, în viitoarele studii va fi necesar să procurăm informaţii de la un număr mai larg de subiecţi care să provină din medii diverse, fiind trataţi în diferite clinici.

Cuvinte cheie: sănătate orală, calitatea vieţii, protezare supraimplantară, implant, edentat total 


\section{INTRODUCERE}

Odată cu apariţia implantologiei în medicina dentară, edentaţiile au început să fie reabilitate prin această terapie (1). Implantologia orală este ştiinţa şi disciplina care se ocupă cu diagnosticul, inserarea, restaurarea şi/sau utilizarea structurilor orale, aloplastice sau autogene, acestea fiind folosite pentru refacerea structurilor morfofuncţionale ale aparatului dentomaxilar (2).

Relaţia dintre medic şi pacient este cel mai important aspect al practicii stomatologice, fiind esenţială în asigurarea diagnosticelor şi tratamentelor (2). În multe cazuri, apar diferenţe între opţiunile de tratament, practicianul fiind nevoit să evidenţieze aspectele nefavorabile ale tratamentului, care pentru pacient par adecvate, dar reuşita va fi pe o perioadă scurtă de timp. Se pot întâlni şi situaţii în care pacienţii au fost nemulţumiţi din cauza calităţii actului terapeutic, costului sau atitudinii medicului (3). După obţinerea informaţiilor, pacientul a acceptat sau a refuzat varianta de tratament propusă, acesta trebuind să specifice alegerea luată în consimţământul informat $(2,3)$. Studiul de faţă a avut ca obiectiv evaluarea satisfacţiei calităţii vieţii pacienţilor edentaţi total, care au fost trataţi prin protezare supraimplantară.

\section{MATERIAL ŞI METODĂ}

Cercetarea este un studiu retrospectiv, cu un lot de 50 de subiecţi, aflaţi în faza de tratament supraimplantar. Pacienţii au răspuns la un chestionar de evaluare a gradului de satisfacţie format din 26 de întrebări, în perioada 2015-2016, în Cluj-Napoca, România. Pacienţii au fost selecţionaţi după următoarele criterii: pacienţi cu edentaţie totală maxilară/mandibulară, tratament prin protezare supraimplantară cu vechime de până la 5 ani, tratament realizat de medici specialişti în chirurgie dento-alveolară, chirurgie oro-maxilo-facială şi protetică dentară, lipsa complicaţiilor pe toată durata tratamentului, aplicarea implanturilor conform conceptului Branemark.

Chestionarul a fost divizat în 3 seturi de întrebări. În prima parte, s-au obţinut informaţii generale legate de pacient (sex, vârstă). În a doua parte, s-a apreciat atitudinea pacienţilor faţă de sănătatea orală proprie, cum a perceput pacientul absența unităţilor dentare, frecvenţa apariţiei problemelor dentare, frecvenţa vizitelor la medicul stomatolog, intervalul de timp scurs între vizite şi motivul pierderii ultimei unităţi dentare. În a treia parte, s-a evaluat gradul de satisfacţie obţinut în urma protezării, cu precădere aspectul noii restaurări protetice, confortul în desfăşurarea funcţiilor aparatului dento-maxilar, prezenţa/absenţa durerii în zona tratată implanto-protetic, prezenţa/absenţa retenţionării de alimente la nivelul lucrărilor protetice şi redarea încrederii în propria persoană

Analiza statistică şi graficele au fost realizate cu programul Microsoft Excel. Datele calitative nominale ordonate au fost evidenţiate prin grafice de tip pie şi tabele de frecvenţă. S-a analizat distribuţia variabilei şi s-au realizat comentarii pe baza datelor din literatura ştiinţifică de specialitate. Pentru variabilele calitative s-au utilizat tabele de contingenţă, graficele de tip coloane fiind interpretate dacă raportul între variabile e proporţional.

\section{REZULTATE}

Pentru prima categorie de întrebări, lotul inclus a cuprins $64 \%$ femei şi $36 \%$ bărbaţi, cu vârste cuprinse între 44 şi 81 ani, având mediana 61 ani (Fig. 1). În ceea ce priveşte atenţia acordată sănătăţii orale, $88 \%$ dintre cei chestionaţi s-au declarat a fi preocupaţi de acest aspect, iar 2\% nu. La întrebarea legată de aspectul dinţilor, 84\% dintre respondenţi au dat un răspuns pozitiv referitor la importanţa acestui subiect, iar 8\% negativ. 64\% dintre pacienţi au fost afectaţi de pierderea dinţilor laterali, iar $80 \%$ au declarat probleme dentare în antecedente (Fig. 2). În ceea ce priveşte vizitele la medicul dentist, 44\% dintre pacienţi obişnuiesc să meargă o dată/an, respectiv $32 \%$ de două ori/an, iar $20 \%$ de mai mult de două ori/an. $86 \%$ dintre cei chestionaţi au precizat cu exactitate vârsta la care şi-au pierdut prima unitate dentară permanentă. Din cadrul lotului studiat, $78 \%$ dintre respondenţi au fost capabili să declare intervalul de timp de când sunt edentaţi total maxilar, respectiv mandibular (80\%). În ceea ce priveşte etiologia edentaţiei totale, $52 \%$ a fost de etiologie carioasă, respectiv $34 \%$ de cauză parodontală (Fig. 3). Pentru a doua categorie de întrebări, înaintea realizării tratamentului pe implanturi, $42 \%$ dintre pacienţi au purtat o proteză totală convenţională, $36 \%$, au fost trataţi 
prin proteze parţiale mobilizabile, iar $22 \%$, prin proteză parţială fixă (Fig. 3).

Pentru a treia categorie de întrebări, 58\% dintre pacienţi s-au declarat foarte mulţumiţi de lucrarea supraimplantară, iar 34\% au fost mulţumiţi, respectiv $6 \%$ au fost moderat mulţumiţi. Un procent de $32 \%$ au considerat noua lucrare protetică foarte confortabilă, $44 \%$ confortabilă, iar $18 \%$ au considerat că tratamentul le-a asigurat un confort moderat (Fig. 3). La aprecierea estetică a lucrării protetice supraimplantare, $48 \%$ dintre pacienţi s-au declarat foarte mulţumiţi, $38 \%$ au fost mulţumiţi, iar $14 \%$ au fost moderat mulţumiţi. În ceea ce priveşte materialul din care s-a realizat proteza, $60 \%$ dintre cei chestionaţi au fost foarte mulţumiţi, $36 \%$ declarându-se mulţumiţi. 14\% dintre participanţii la studiu au prezentat durere la nivelul zonelor tratate implanto-protetic, iar $43 \% \mathrm{nu}$ au prezentat durere. $\mathrm{Cu}$ privire la capacitatea masticatorie, $92 \%$ dintre pacienţi au redobândit capacitatea de a mes- teca normal, iar $8 \%$ nu s-au adaptat cu noile structuri protetice. Un procent de $72 \%$ dintre pacienţi pot muşca alimente dure, $24 \%$ declarând că nu au posibilitatea de muşca alimente cu consistenţă crescută. 94\% dintre respondenţi au declarat că plăcerea de a mesteca a revenit, $6 \%$ neagă acest aspect (Fig. 4). În ceea ce priveşte igienizarea lucrării supraimplantare, $92 \%$ dintre cei chestionaţi o consideră simplă şi facilă, pe când $12 \%$ o consideră cu grad de dificultate ridicat. $98 \%$ dintre pacienţi au confirmat o creştere a încrederii în sine postterapeutic, iar restul de $2 \%$ au răspuns negativ. $96 \%$ dintre pacienţi nu au prezentat mobilitate la nivelul lucrării supraimplantare, iar $86 \%$ au declarat că nu a existat retenţie alimentară la acest nivel. Atitudinea faţă de o nouă intervenţie implantară a fost pozitivă la 40\% dintre cei chestionaţi, respectiv negativă la 48\% dintre ei. $90 \%$ dintre respondenţi au preferat protezarea fixă, iar 10\% protezarea mobilizabilă (Fig. 5).

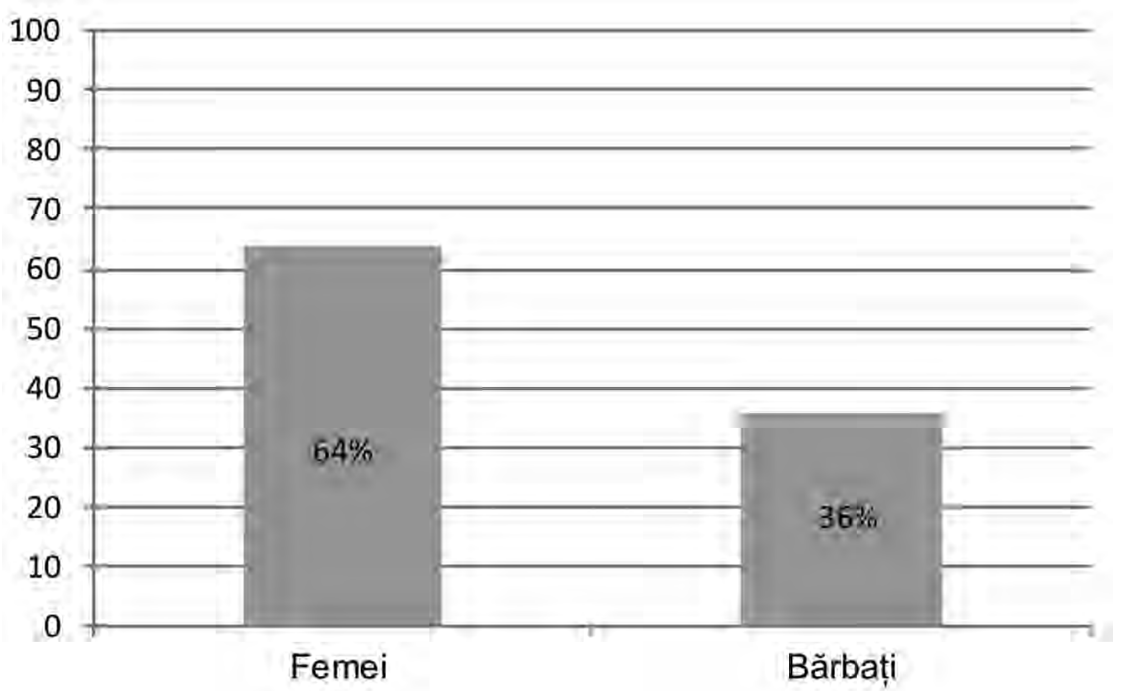

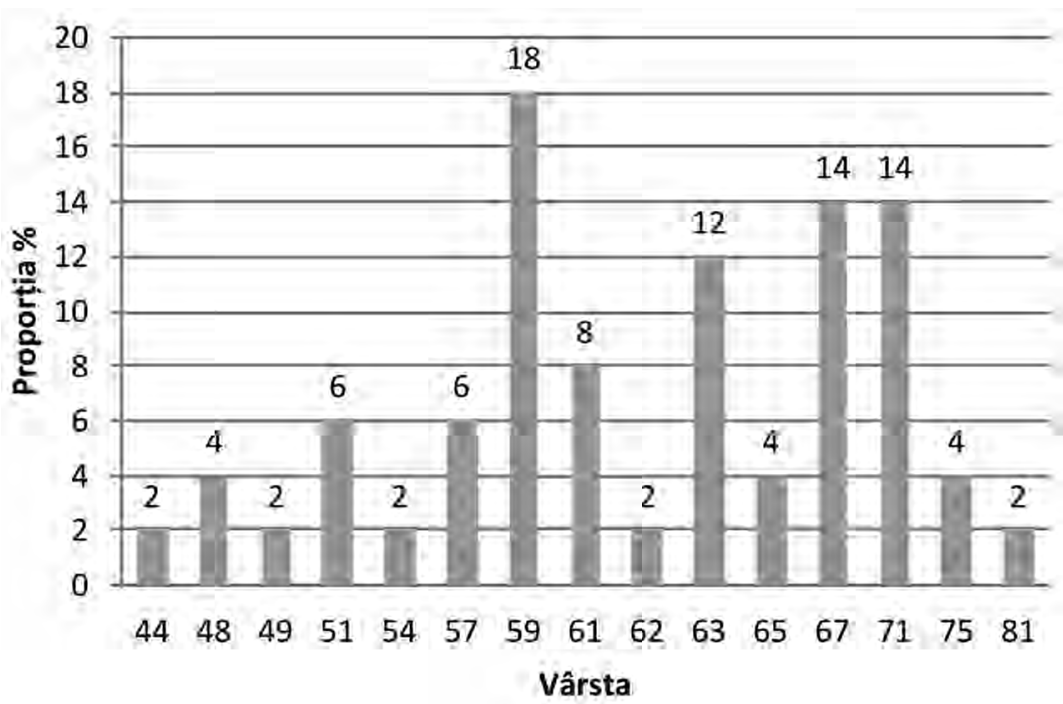

FIGURA 1. Distributtia pe sexe şi pe vârste a pacienților 


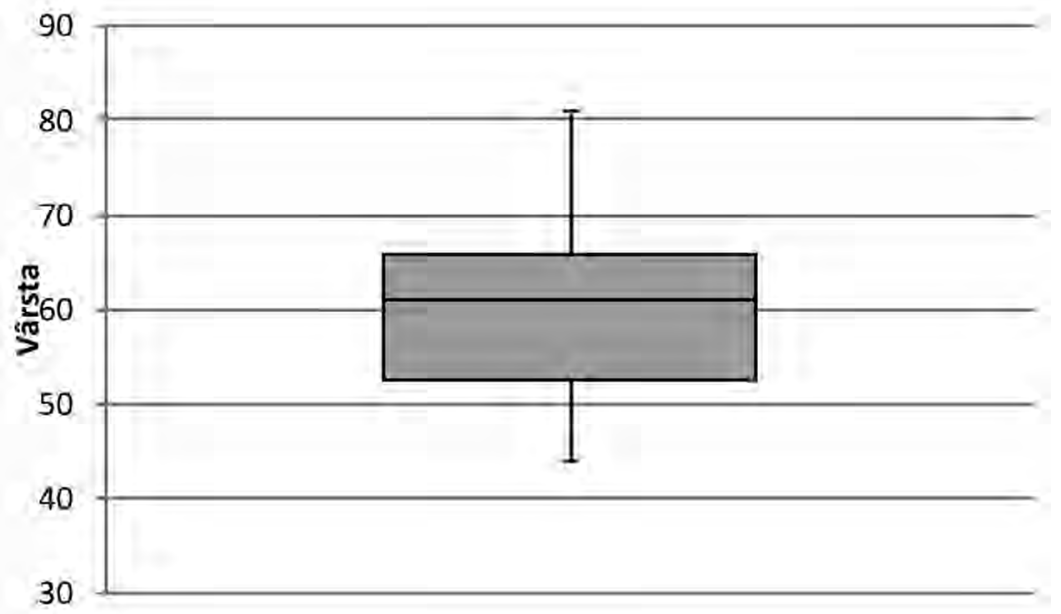

FIGURA 1. Distribuția pe sexe şi pe vârste a pacienților (continuare)

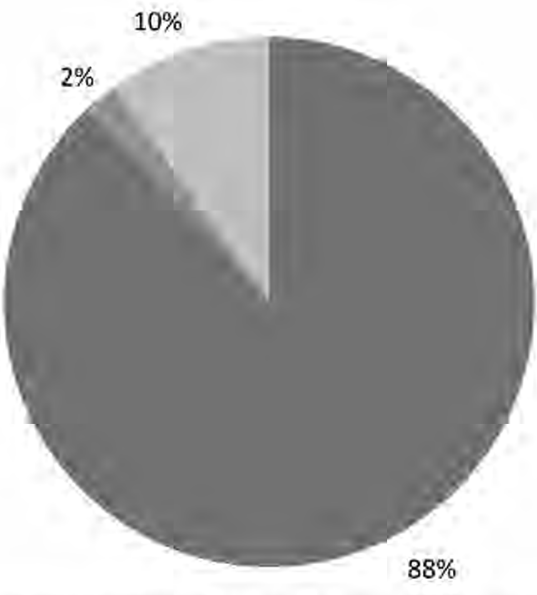

Este importantă sănătatea dinților pentru dumneavoastră?

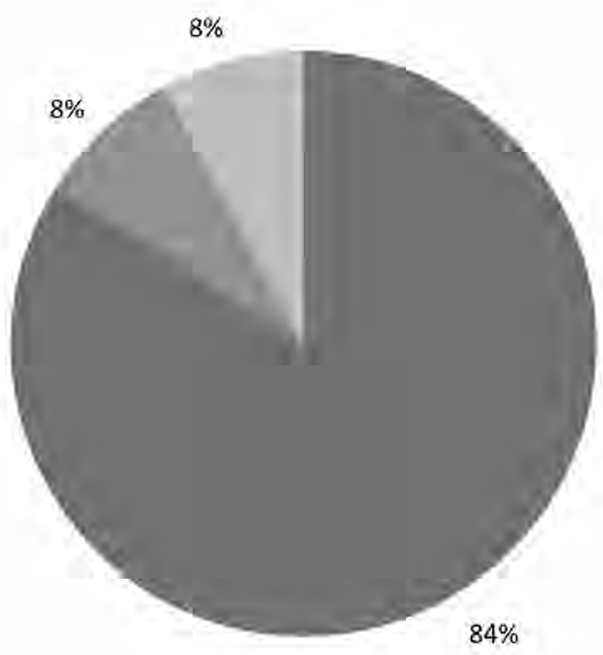

Ați avut des probleme dentare?

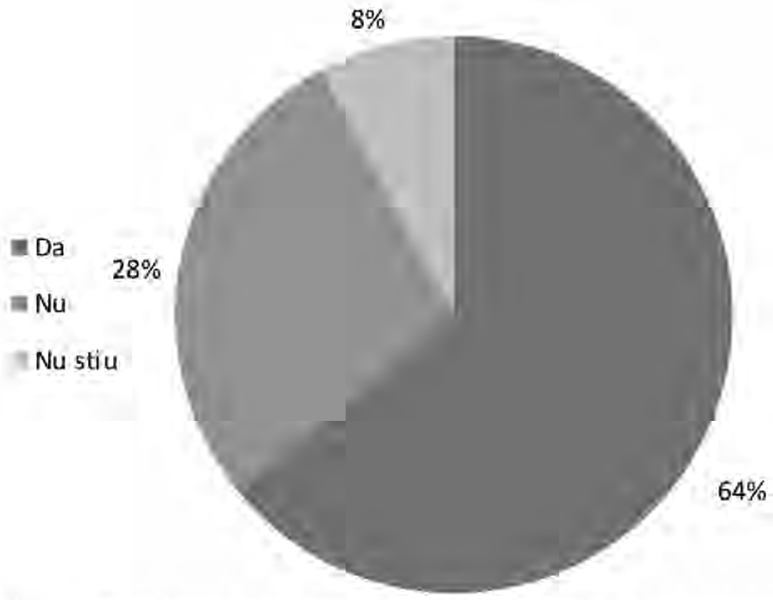

Este important aspectul dinților pentru dumneavoastră?

$4 \%$

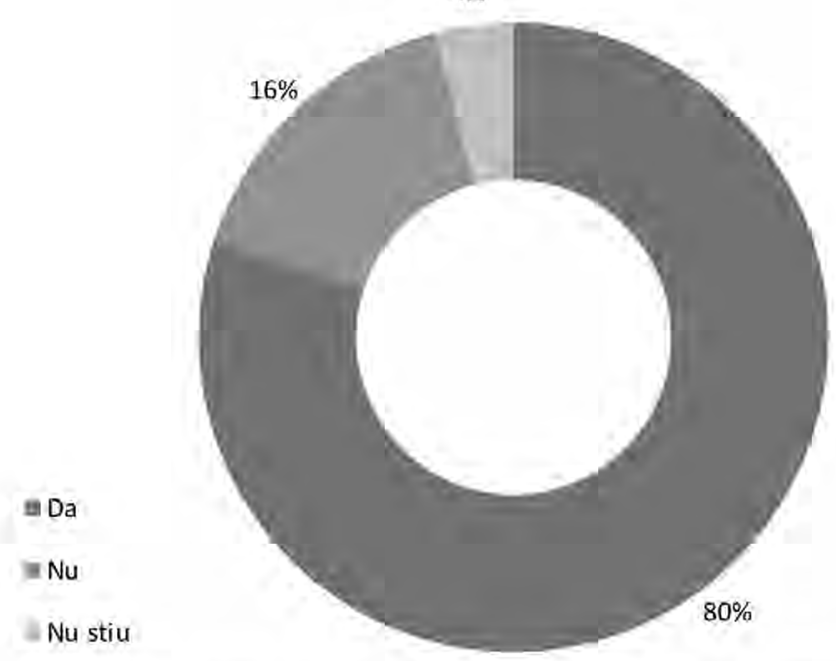

V-a afectat pierderea dinților laterali de pe arcada dentarā?

\section{wa \\ in $\mathrm{Nu}$}

vu stiu

FIGURA 2. Repartiția pacienților în procente cu privire la importanța acordată sănătății dentare, aspectul dentar, problemele dentare apărute 


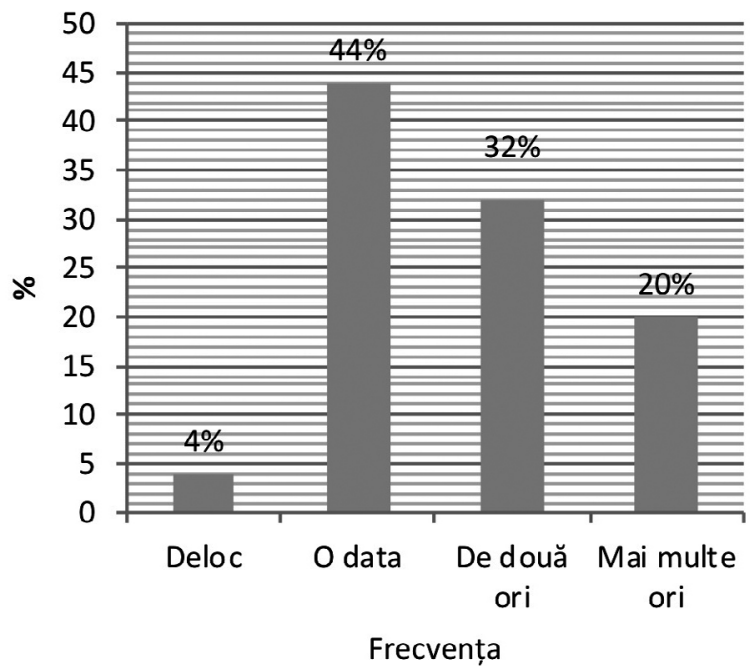

Frecvența vizitelor la medicul dentist

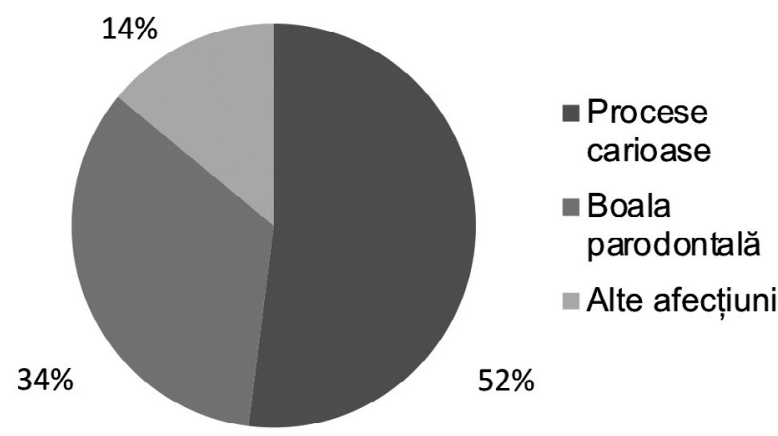

Etiologia edentației totale

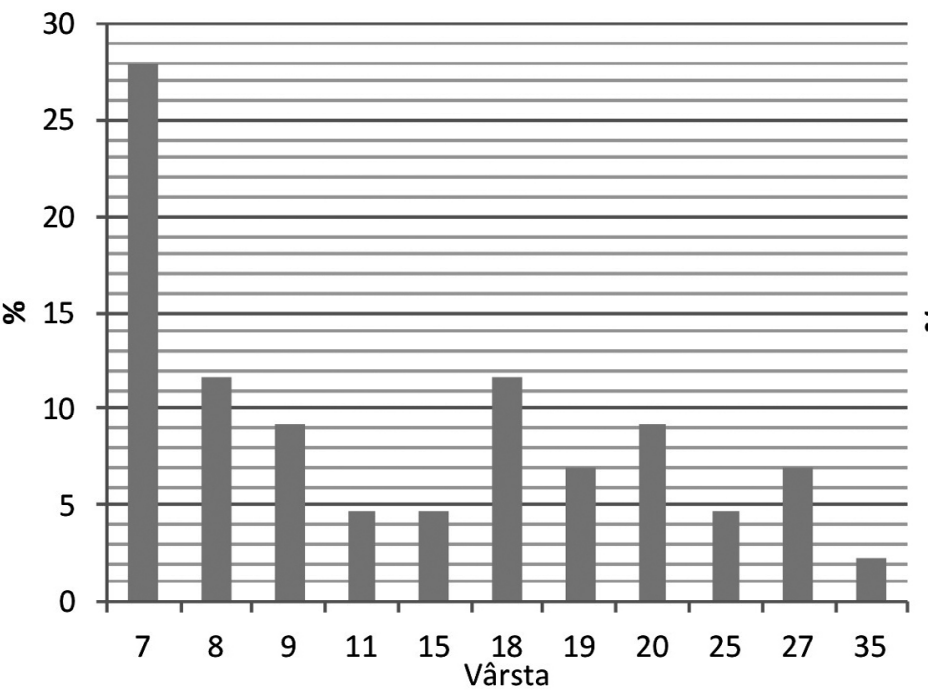

Reprezentarea în procente al pacienților care și-au pierdut primul dinte permanent la diferite vârste

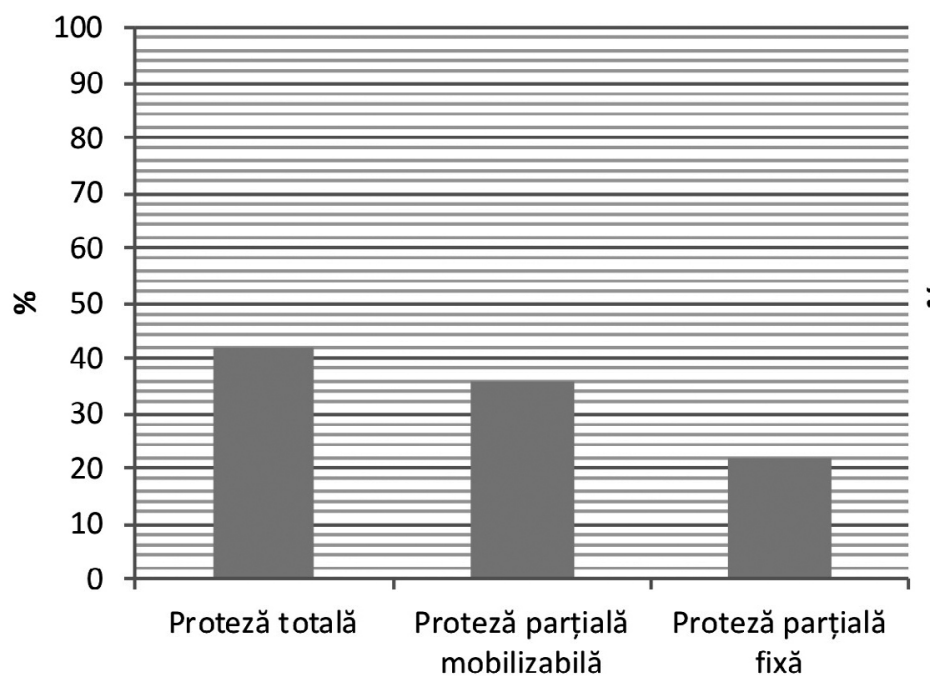

Tipul de tratament protetic anterior protezării supraimplantare

FIGURA 3. Repartiția pacienților cu privire la frecvența vizitelor la medicul stomatolog, vârsta la care şi-au pierdut prima unitate dentară, intervalul de timp înregistrat de la absența ultimei unități dentare de pe maxilar/mandibulă, etiologia edentației, tipul anterior de tratament protetic, gradul de mulțumire şi confort cu noua lucrare protetică supraimplantară 


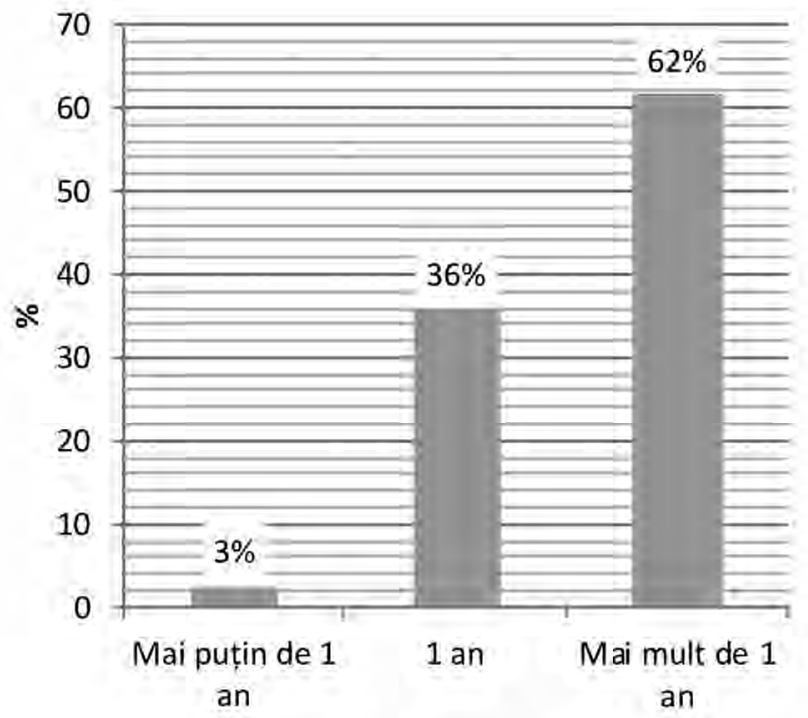

Intervalul de timp înregistrat de la pierderea ultimului dinte de pe arcada maxilară

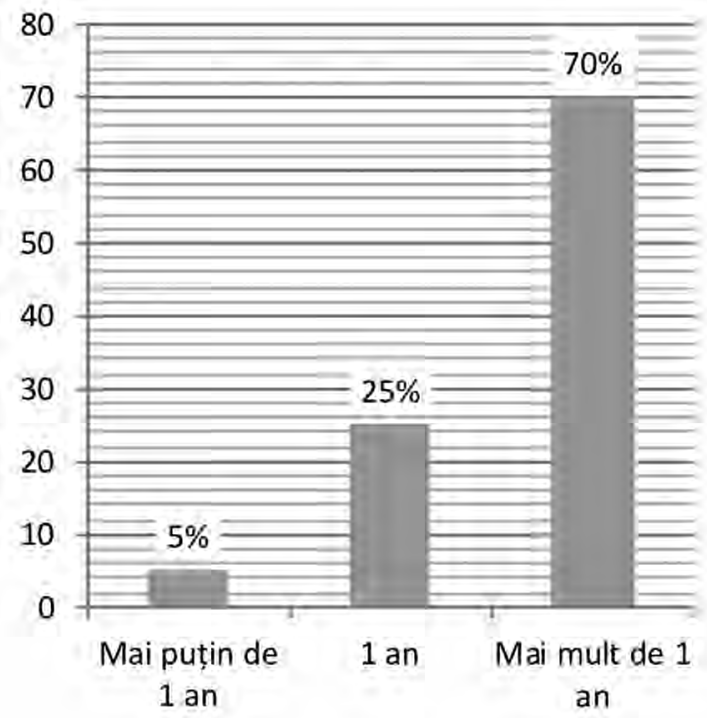

Intervalul de timp înregistrat de la pierderea ultimului dinte de pe arcada mandibulară
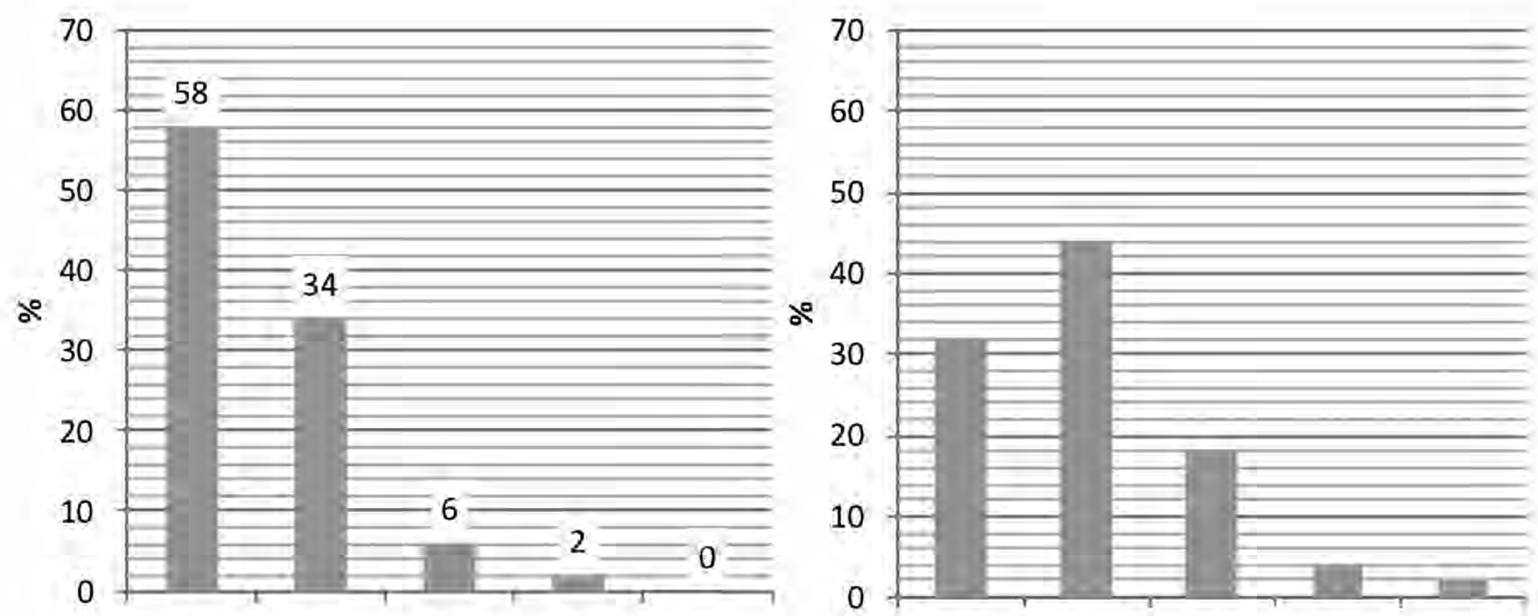

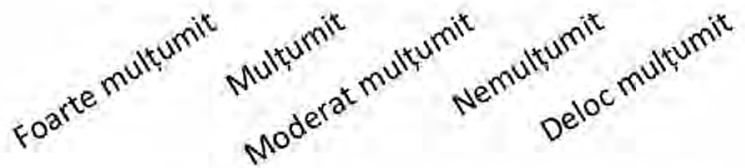

Gradul de mulțumire cu noua lucrare protetică supraimplantară

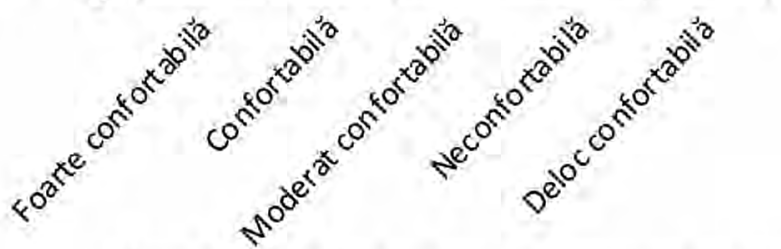

Gradul de confort al lucrării supraimplantare

FIGURA 3. Repartiția pacienților cu privire la frecvența vizitelor la medicul stomatolog, vârsta la care şi-au pierdut prima unitate dentară, intervalul de timp înregistrat de la absența ultimei unități dentare de pe maxilar/mandibulă, etiologia edentației, tipul anterior de tratament protetic, gradul de mulțumire şi confort cu noua lucrare protetică supraimplantară (continuare) 

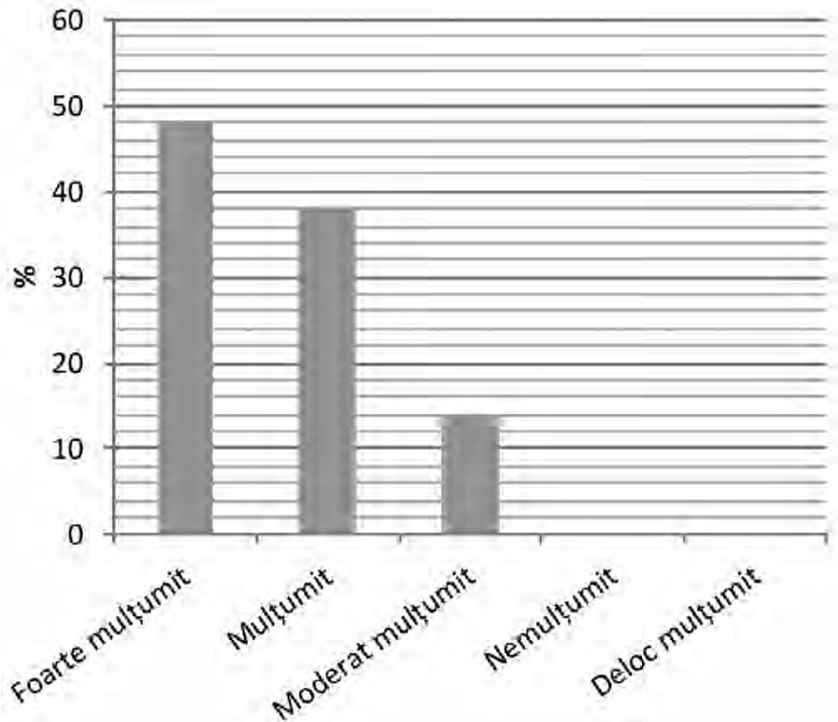

Gradul de satisfacţie estetică

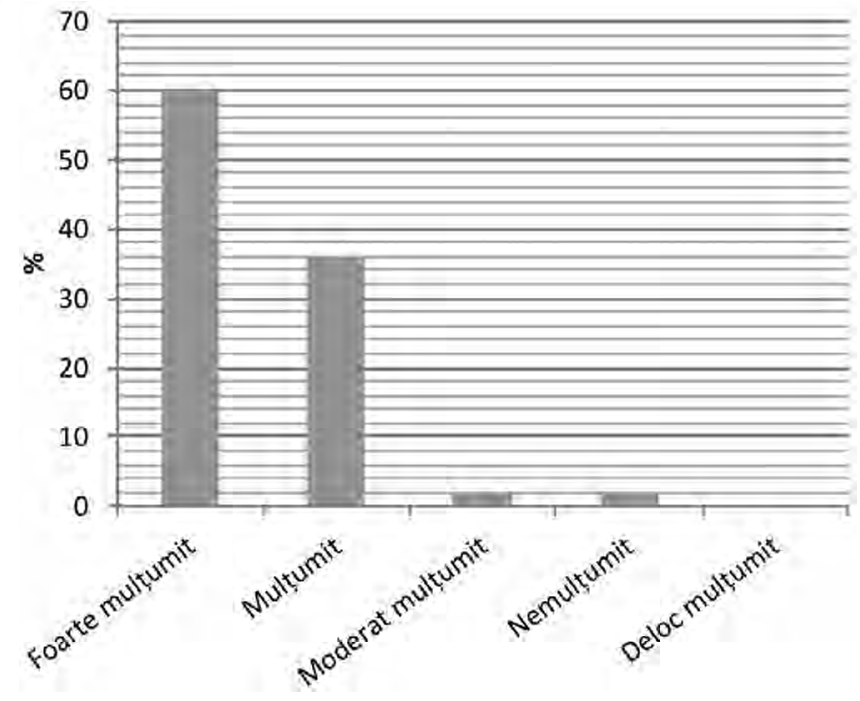

Aprecierea materialului din care s-a confecţionat lucrarea supraimplantară

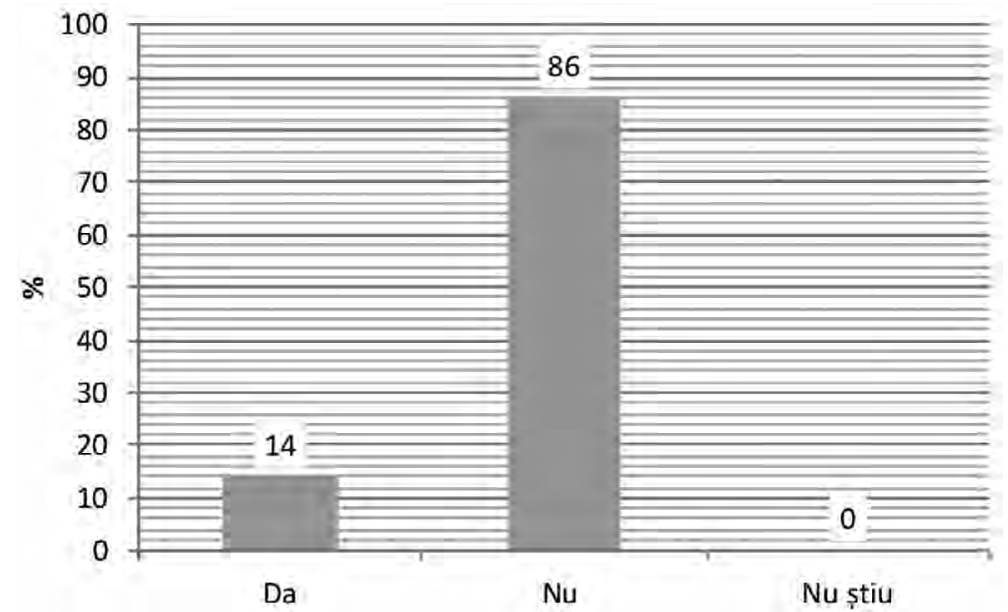

Durere la nivelul zonei implanturilor

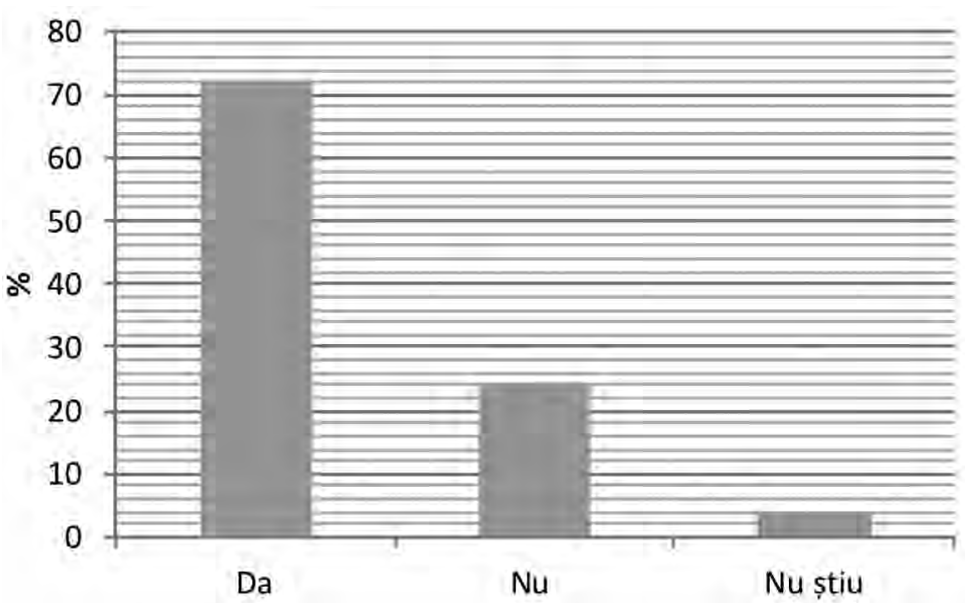

Capacitatea de a mânca alimente de consistenţă dură

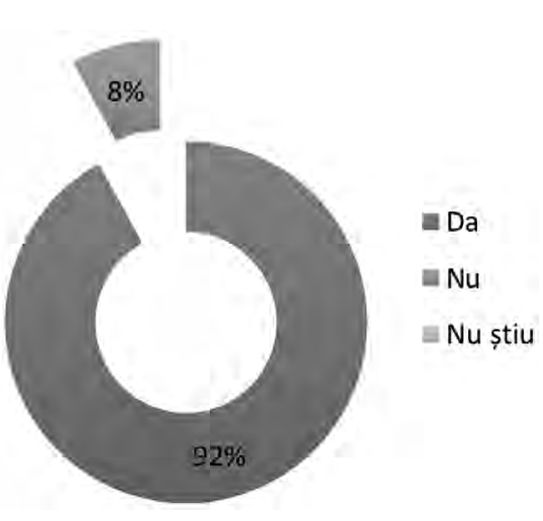

Capacitatea de a realiza funcţia masticatorie

FIGURA 4. Repartiția pacienților cu privire la gradul de satisfacție estetică, aprecierea materialului lucrării supraimplantare, prezența durerii postoperatorii, capacitatea de a realiza masticația, de a utiliza alimente de consistență solidă şi redobândirea plăcerii de a mesteca 


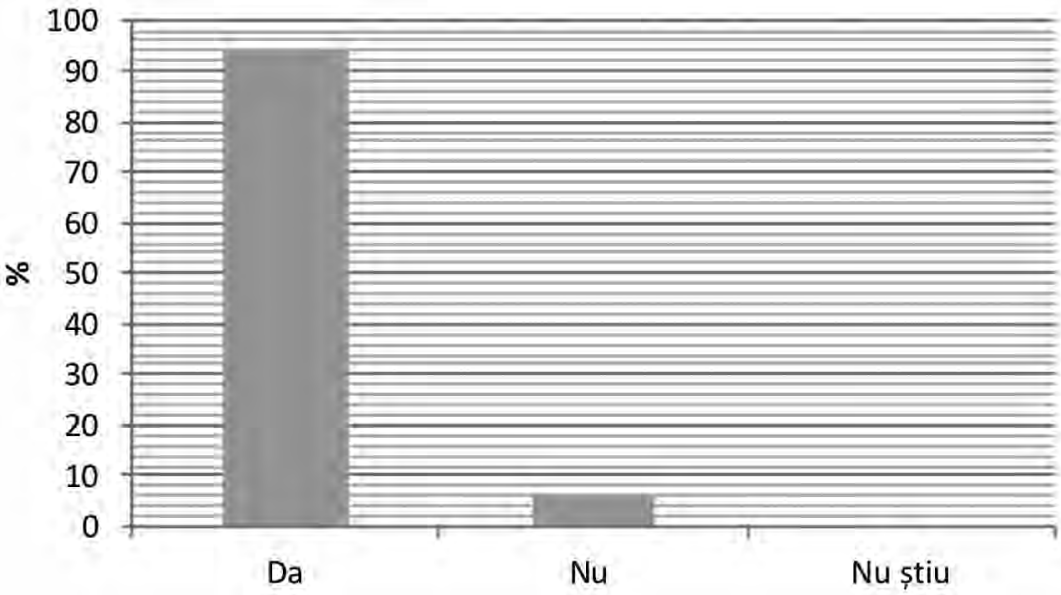

FIGURA 4. Repartiția pacienților cu privire la gradul de satisfacție estetică, aprecierea materialului lucrării supraimplantare, prezența durerii postoperatorii, capacitatea de a realiza masticația, de a utiliza alimente de consistență solidă şi redobândirea plăcerii de a mesteca (continuare)

Redobândirea plăcerii de masticaţie

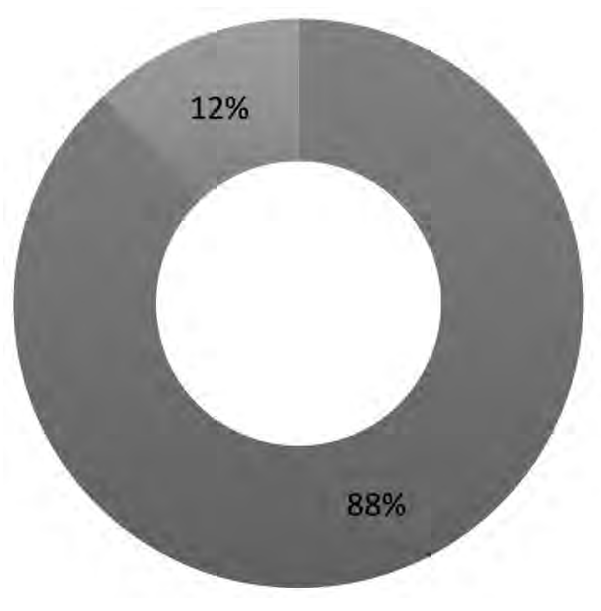

Igienizarea lucrării supraimplantare

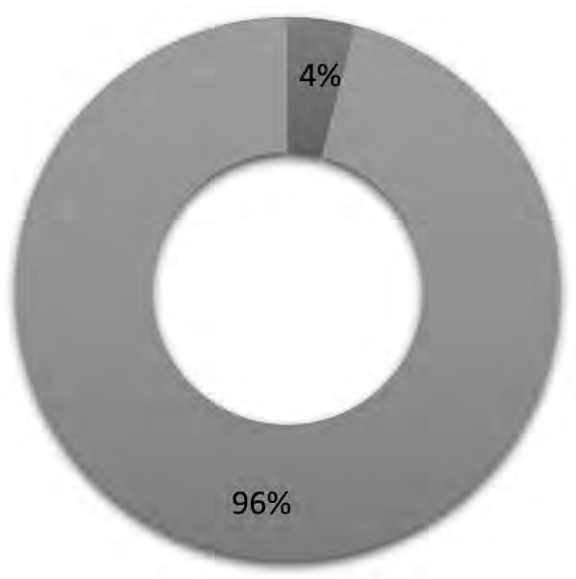

Mobilitatea lucrării supraimplantare
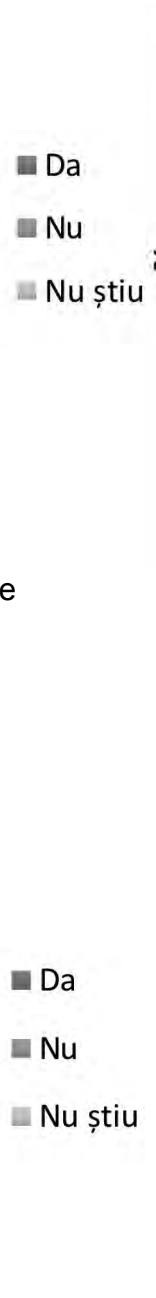
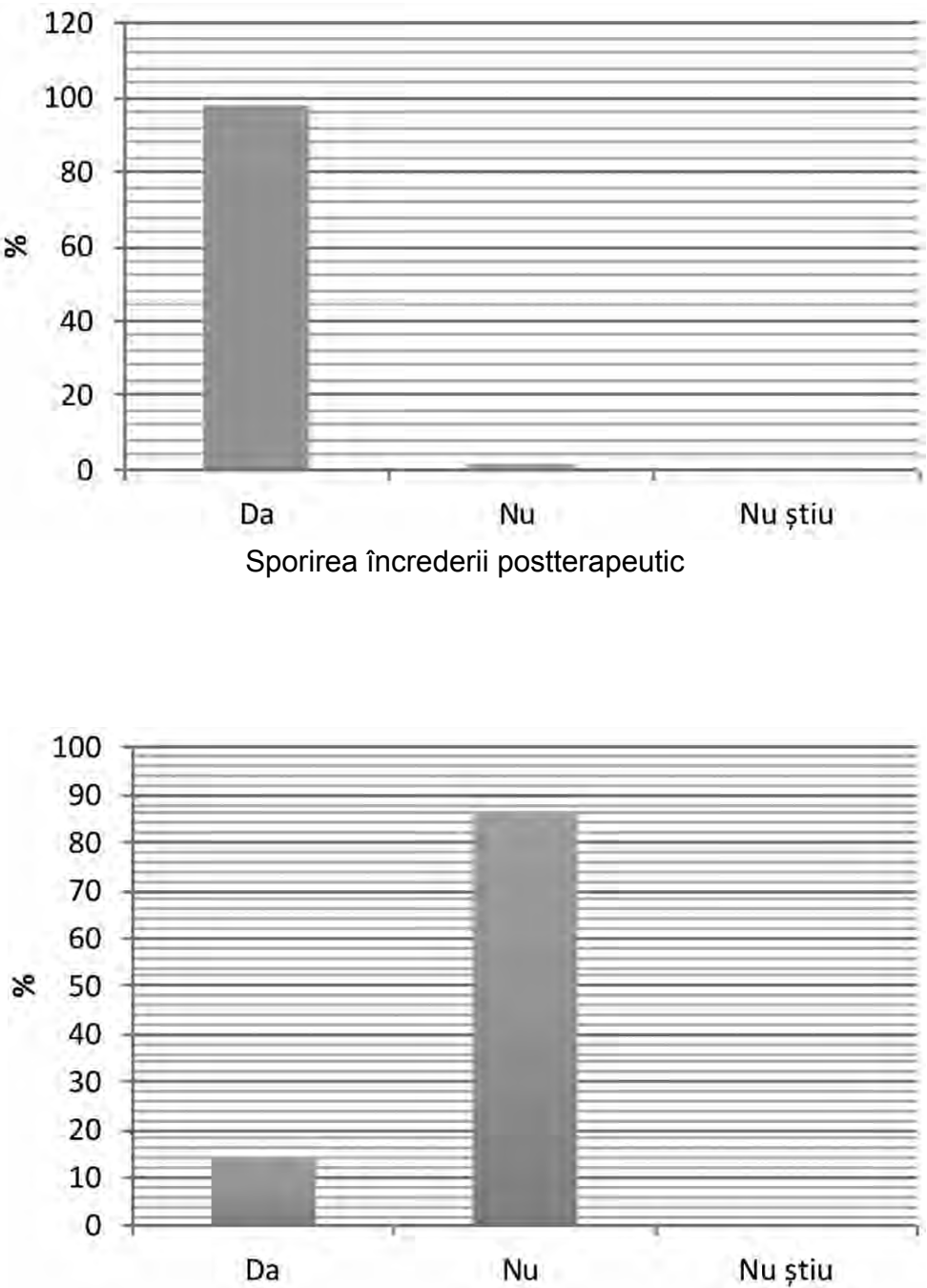

Retenţionarea alimentelor la nivelul lucrării supraimplantare

FIGURA 5. Repartiția pacienților cu privire la igienizarea lucrărilor supraimplantare, sporirea încrederii postterapeutic, mobilitatea lucrărilor supraimplantare, retenționarea de resturi alimentare la nivelul lucrărilor supraimplantare, atitudinea față de o nouă intervenție terapeutică implantară, preferința pentru lucrările fixe comparativ cu cele mobilizabile 


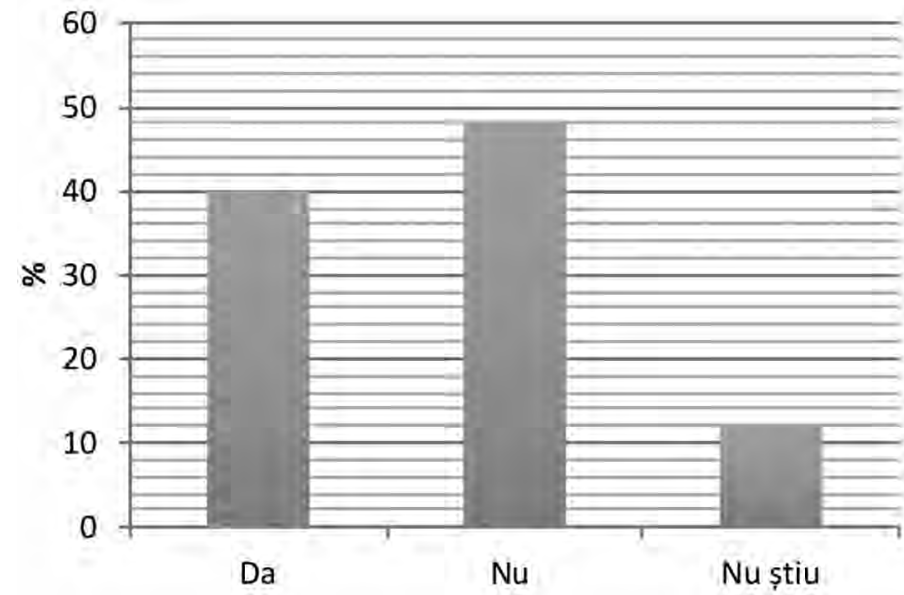

Atitudinea faţă de o eventuală reluare a tratamentului

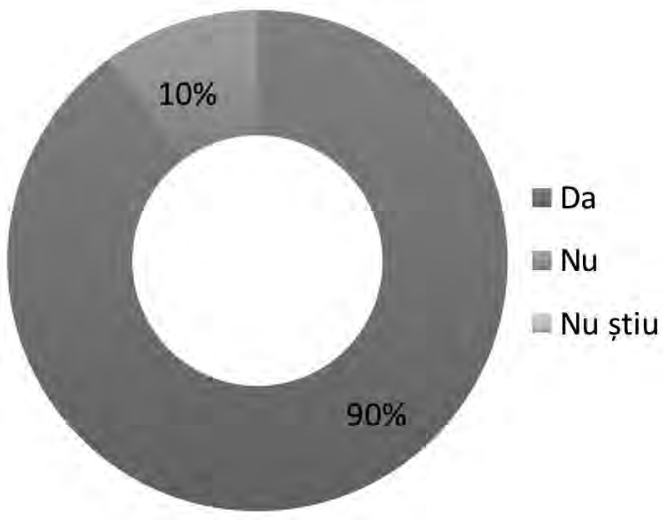

Preferinţa unei lucrări fixe în detrimentul unei lucrări mobilizabile

FIGURA 5. Repartiția pacienților cu privire la igienizarea lucrărilor supraimplantare, sporirea încrederii postterapeutic, mobilitatea lucrărilor supraimplantare, retenționarea de resturi alimentare la nivelul lucrărilor supraimplantare, atitudinea față de o nouă intervenție terapeutică implantară, preferința pentru lucrările fixe comparativ cu cele mobilizabile (continuare)

\section{DISCUȚII}

Scopul studiului a fost de a evalua satisfacţia pacienţilor edentaţi total prin protezare supraimplantară. Cercetarea a înregistrat un procent mai mare cu $28 \%$ a pacienţilor de sex feminin comparativ cu cei de sex masculin. Rezultatele obţinute corespund cu cele realizate de către Dervis şi colaboratorii (4). Rezultatele studiului nu au fost influenţate de parametrii sex sau vârstă, dar calitatea unităţilor dentare a făcut diferenţa între grupurile de pacienţi (4). Rezultatele indică faptul că femeile sunt mai interesate de propria persoană şi, implicit, de sănătatea orală, datorită îngrijirii permanente ale acestora. Nu trebuie ignorat faptul că femeile au o longevitate mai mare decât a bărbaţilor (5). Distribuţia pe vârste a arătat un procent ridicat de pacienţi cu vârste de peste 57 ani $(78 \%$ dintre respondenţi). Acest aspect este normal, deoarece pacienţii care sunt edentaţi total sunt încadraţi în categoria de vârstă maximă posibilă (6).

La întrebările cu privire la sănătatea orală, respectiv la aspectul unităţilor dentare, subiecţii s-au dovedit a fi foarte interesaţi de aceste deziderate. Pierderea ultimelor unităţi dentare a constituit un element important în detectarea unei posibile apariţii a afecţiunilor psihice în rândul pacienţilor edentaţi total. Unele studii nu au găsit asocieri între declinul psihic-cognitiv al pacienţilor adulţi, precizând că pierderea unităţilor dentare ar fi un potenţial semn al declinului psihic (6). Ţara noastră a prezentat o schimbare drastică a bugetului public şi privat îndreptat către serviciile de medicină dentară. Alocarea unui buget public insuficient din fondul de asigurări sociale de sănătate a determinat crearea unei dependenţe de mediul privat. Drept urmare, alocarea fondurilor din bugetul public al ţării noastre îndreptată spre sănătatea orală creşte într-un ritm foarte lent comparativ cu celelalte state ale Uniunii Europene (7).

Răspunsurile referitoare la întrebarea privind pierderea primei unităţi dentare permanente indică faptul că $28 \%$ dintre pacienţi au devenit edentaţi de la vârsta de 7 ani. Acest aspect sugerează o carenţă apărută în informarea părinţilor şi copiilor referitor la sănătatea orală. Etiologia edentaţiei totale a fost reprezentată de boala parodontală, respectiv de procesele carioase multiple lăsate netratate. Pacienţii au declarat îmbunătăţirea confortului (76\%), cu lipsa durerii (86\%) postoperator, precum şi îmbunătăţirea funcţiei estetice $(86 \%)$ după realizarea tratamentului implanto-protetic. De asemenea, pacienţii au menţionat că au redobândit plăcerea de a mesteca (94\%). Lipsa mobilităţii lucrării protetice pe implanturi a fost declarată de $96 \%$ dintre pacienţi. În ceea ce priveşte igienizarea lucrărilor supraimplantare, pacienţii au fost mulţumiţi, declarând că se realizează uşor şi rapid (92\%). Există cercetări care au indicat că utilizarea periuţei cu partea activă dublă determină o îmbunătăţire a statusului structurilor periimplantare (8). 
$48 \%$ dintre pacienţi nu au dorit să mai treacă prin tratamentul cu protezare pe implanturi. Rezultatul denotă faptul că pacienţilor nu le-a fost uşor să urmeze etapele chirurgicale. Literatura de specialitate menţionează că pacienţii afectaţi prezintă tipuri diferite de personalitate, dovedindu-se că anumite trăsături, precum nevroza, au un impact notabil asupra stării psihice postoperatorii (9). Proteza supraimplantară fixă a fost preferată de către pacienţi, comparativ cu proteza mobilizabilă $(45 \%$ au răspuns pozitiv). Orice persoană îşi doreşte ca unităţile dentare pierdute să îi fie reabilitate prin structuri asemănătoare cu cele avute anterior (10-13). Datorită faptului că lucrările pe implanturi nu au mobilitate, ele conferă pacientului un confort psihic crescut şi recâştigarea încrederii în sine (10-13). Apariţia implanturilor cu încărcare imediată îmbunătăţeşte şi mai mult calitatea vieţii pacienţilor edentaţi maxilar sau mandibular mai ales în primul an postoperator (13-18). Studiile efectuate au demonstrat că cel puţin pe termen scurt tratamentul cu implanturi îmbunătăţeşte semnificativ calitatea vieţii pacienţilor comparativ cu tratamentul protetic convenţional $(13,14,17,18)$. În literatura de specialitate a fost indicat faptul că pacienţii protezaţi prin terapie supraimplantară au prezentat un mai mare grad de satisfacţie comparativ cu pacienţii protezaţi prin lucrări convenţionale (10-12,16-19). De asemenea, s-a observat că, în evaluarea sănătăţii orale a pacienţilor, trebuie luat în considerare simultan statusul oral, dar şi dimensiunea socială şi impactul psihologic al tratamentului pe implanturi $(14,20)$. Totuşi, definirea şi măsurarea calităţii vieţii corelată cu sănătatea orală implică folosirea unor judecăţi subiective, fiind practic echivalată cu satisfacţia profundă ce rezultă din efectuarea cu succes a activităţilor zilnice $(15,21)$. Din păcate, în stomatologie, noţiunea de „calitatea vieţii“ a fost rareori folo- sită in evaluarea sănătăţii orale, deşi statusul dentar influenţează calitatea vieţii pacienţilor $(16,22,23)$. Se poate pune, totodată, întrebarea „Cine poate măsura mai bine calitatea vieţii, medicul sau pacientul?“. Studiile de specialitate au arătat că aprecierea calităţii vieţii trebuie să vină din partea pacienţilor (17-19). S-a observat implicarea tot mai activă a pacienţilor în luarea deciziilor privind tratamentele cu implanturi. De aceea, înţelegerea aşteptărilor pacienţilor referitor la estetică şi refacerea funcţională a reprezentat cheia succesului în tratamentul implanto-protetic $(19,24)$. Studiile de specialitate arată că profesioniştii din domeniul serviciilor de sănătate au acceptat existenţa unei legături între aşteptările pacienţilor şi nivelul de satisfacţie obţinut după terminarea tratamentului pe implanturi $(19,24,25)$.

\section{CONCLUZII}

Această cercetare preliminară a evidenţiat principalele aspecte legate de satisfacţia pacienţilor pre- şi postoperator, în cadrul tratării lor prin protezarea pe implanturi. Pentru a reflecta corect realitatea, în viitoarele studii va fi necesar să culegem informaţii de la un număr mai larg de subiecţi, care să provină din medii diverse şi cu tratamente realizate în diferite clinici.

\section{Mențiune}

Toţi autorii declară că nu există niciun conflict de interese. Înaintea aplicării chestionarului, pacienţii au fost de acord cu includerea în studiu şi au semnat consimţământul informat. Ondine Lucaciu, Simion Bran, Florin Onişor şi Sorina Sava au contribuit în mod egal la realizarea acestui articol ca şi primul autor.

\section{BIBLIOGRAFIE}

1. Jakse Misch CE. Contemporary Implant Dentistry. Elsevier Mosby. 3rd ed. 2008:3-16,178-213,233-270.

2. Zarb GA, Hobkirk J, Eckert S, Jacob R. Prosthodontic Treatment for Edentulous Patients, Complete Dentures and Implant-Supported Protheses. Elsevier, Mosby. 2013:330-45.

3. Bergendal $B$. The relative importance of tooth loss and denture wearing in Swedish adults, Community Dent Health. 1989;6(2):10311.

4. Dervis E. Clinical assessment of common patient complaints with complete dentures. Eur J Prosthodont Restor Dent. 2002 Sep;10(3):113-7.

5. Glick M, Monteiro da Silva O, Seeberger GK et al. FDI Vision 2020: Shaping the future of oral health. Int Dent J. 2012;62:278-91.

6. Tsakos G, Watt RG, Rouxel PL, de Oliveira C, Demakakos P. Tooth loss associated with physical and cognitive decline in older adults. $J$ Am Geriatr Soc. 2015;63(1):91-9.

7. Oancea $R$, Amariei $C$, Eaton KA, Widstrom $E$. The healthcare system and the provision of oral healthcare in European Union member states: Part 5: Romania. Br Dent J. 2016;220(7):361-6.

8. Mall P, Singh K, Singh SV, Agrawal KK, Siddharth R, Chand P. Management of overdenture abutments health by an innovative cleaning aid. BMJ Case Rep. 2012;2012.pii: bcr2012007390. 
9. Abu Hantash RO, Al-Omiri MK, Al-Wahadni AM. Psychological impact on implant patients' oral health-related quality of life, Clin Oral Implants Res. 2006;17(2):116-23.

10. De Bruyn H, Raes S, Matthys C, Cosyn J. The current use of patient-centered/reported outcomes in implant dentistry: A systematic review, Clin Oral Implants Res. 2015;26 Suppl 11:45-56.

11. Lucaciu OP, Balan R, Bordea R, Campian RS. Evaluarea impactului lucrărilor protetice supraimplantare asupra calităţii vieţii pacienţilor. Calitatea vieții, Nr. special. Bucureşti, Editura Academiei Române. 2017:99-100.

12. Lucaciu OP, Balan R, Bordea R, Campian RS. Evaluarea impactului lucrărilor protetice supraimplantare asupra calităţii vieţii pacienţilor. Antropologie şi demografie. Bucureşti, Editura Academiei Române. 2018:396-402

13. Awad MA, Locker D, Korner-Bitensky N, Feine JS. Measuring the effect of intra-oral implant rehabilitation on health-related quality of life in a randomized controlled clinical trial. J Dent Res. 2000; 79:1659-63.

14. Leao A, Sheiham A. Relation between clinical dental status and subjective impacts on daily living. J Dent Res. 1995; 74:1408-13.

15. Mester A, Apostu D, Ciobanu $L$ et al. The impact of proton pump inhibitors on bone regeneration and implant osseointegration. Drug Metab Rev. 2019:1-10. doi: 10.1080/03602532.2019.1610767. (Epub ahead of print)

16. Reisine ST, Fertig J, Weber J, Leder S. Impact of dental conditions on patients' quality of life. Comm Dent Oral Epidemiol. 1989;17:7-10.
17. Slevin $M L$, Plant $H$, Lynch $D$ et al. Who should measure quality of life, the doctor or the patient? British Journal of Cancer. 1988;57:109-12.

18. Erkapers M, Segerström S, Ekstrand K et al. The influence of immediately loaded implant treatment in the atrophic edentulous maxilla on oral health related quality of life of edentulous patients: 3-year results of a prospective study. Head Face Med. 2017;13:21.

19. Jie Yao, Hua Tang, Xiao-Li Gao, Colman McGrath, Nikos Mattheos. Patients' expectations to dental implant: a systematic review of the literature. Health Qual Life Outcomes. 2014;12:153.

20. Gift HC, Atchison KA, Dayton CM. Conceptualizing oral health and oral health-related quality of life. Soc Sci Med. 1997;44:601-8.

21. Higginson IJ, Carr AJ. Measuring quality of life: Using quality of life measures in the clinical setting. BMJ. 2001;322:1297-300.

22. Tarcea M, Fazakas Z, Szucs V et al. Mean dietary fiber intake of Romanian adults - results of a survey questionnaire. Rev. Chim. (Bucharest). 2017;68(9):2083-7.

23. Allen PF. Assessment of oral health related quality of life. Health Qual Life Outcomes.2003;1:40.

24. Shane JJ McCrea. An Analysis of Patient Perceptions and Expectations to Dental Implants: Is There a Significant Effect on Long-Term Satisfaction Levels? Int J Dent. 2017;2017:8230618.

25. Vigu AL, Stanciu D, Lotrean LM, Campian RS. Complex interrelations between self-reported oral health attitudes and behaviors, the oral health status, and oral health-related quality of life. Patient Prefer Adherence. 2018;12:539-49. 